\title{
Ultrasound-Assisted Emulsification Microextraction of Trace Amounts of Co and Mn Ions Prior to Flame Atomic Absorption Spectrometry
}

\author{
Sayed Z. Mohammadi, ${ }^{*, a}$ Daryoush Afzali, ${ }^{b}$ \\ Yar M. Baghelani ${ }^{a}$ and Laleh Karimzadeh ${ }^{a}$
}

${ }^{a}$ Department of Chemistry, Payame Noor University (PNU), Kerman, Iran ${ }^{b}$ Nanochemistry and Environment Department, Institute Research of Environmental Sciences,
International Center for Science, High Technology \& Environmental Sciences, Kerman, Iran

\begin{abstract}
O presente trabalho descreve um procedimento para emulsificação-microextração de quantidades traço de íons cobalto e manganês sem uso de ligantes, assistido por ultrasom, em amostras de água. Os metais extraídos foram determinados por espectrometria de absorção atômica em chama (FAAS). Foram estudados e otimizados diversos fatores que influenciam a eficiência de extração de íons cobalto e manganês, tais como tipo e volume do solvente de extração, pH, tempo de extração, temperatura de extração e força iônica. Íons cobalto e manganês foram extraídos em um meio emulsificado acusticamente com $20,0 \mu \mathrm{L}$ de tetracloreto de carbono. Os limites de detecção foram 0,8 e $0,5 \mathrm{ng} \mathrm{mL}^{-1}$ para $\mathrm{Co}(\mathrm{II})$ e $\mathrm{Mn}(\mathrm{II})$, respectivamente $(3 \mathrm{~S} / \mathrm{m})$. Oito determinações em replicata de uma mistura de $100,0 \mathrm{ng} \mathrm{mL}^{-1}$ de cobalto e $50,0 \mathrm{ng} \mathrm{mL}^{-1}$ de manganês resultaram em absorbâncias média de 0,055 e 0,061 com desvios padrão relativos de 3,2\% e 2,9\%, respectivamente. $\mathrm{O}$ procedimento proposto foi aplicado com sucesso na determinação de cobalto e manganês em amostras de água.
\end{abstract}

The present work reports a procedure based on ligandless-ultrasound-assisted emulsificationmicroextraction of trace amounts of cobalt and manganese ions in water samples prior to flame atomic absorption spectrometry determination (FAAS). Different factors influencing the extraction efficiency of cobalt and manganese ions, such as type and volume of the extraction solvent, $\mathrm{pH}$, extraction time, extraction temperature, and ionic strength were studied and optimized. Cobalt and manganese ions were extracted in an acoustically emulsified media by $20.0 \mu \mathrm{L}$ carbon tetrachloride. The limits of detection were 0.8 and $0.5 \mathrm{ng} \mathrm{mL}^{-1}$ for $\mathrm{Co}(\mathrm{II})$ and $\mathrm{Mn}(\mathrm{II})$, respectively $\left(3 \mathrm{~S}_{\mathrm{b}} / \mathrm{m}\right)$. Eight replicate determinations of a mixture of $100.0 \mathrm{ng} \mathrm{mL}^{-1}$ cobalt and $50.0 \mathrm{ng} \mathrm{mL}^{-1}$ manganese gave a mean absorbance of 0.055 and 0.061 with relative standard deviations of 3.2 and $2.9 \%$, respectively. The proposed procedure was successfully applied to determination of cobalt and manganese in water samples.

Keywords: ultrasound-assisted extraction, emulsification microextraction, ligandless, preconcentration, cobalt, manganese

\section{Introduction}

In general, heavy metal ions are toxic, non-biodegradable, and tend to be accumulated in vital human organs, where they can act progressively over a long period through food chains. The determination of trace heavy metal ions in environmental samples has received increasing attention. ${ }^{1-3}$ However, due to the complexity of sample matrix and the frequently low concentrations of metals, there is a crucial need for the extraction and preconcentration of trace

*e-mail: szmohammadi@yahoo.com elements from matrix before their analysis using atomic absorption spectrometry. To obviate these problems, an effective extraction and preconcentration method is necessary.

Liquid-liquid extraction (LLE) ${ }^{4,5}$ and solid-phase extraction (SPE) $)^{6,7}$ are commonly used liquid sample pretreatment methods. LLE is among the oldest and more widespread techniques for the extraction of a wide range of organic pollutants from water samples. Nevertheless, LLE is time-consuming, requires large amounts of organic solvents that are potentially toxic, and is difficult to automate. SPE uses less solvent than LLE but can 
be relatively expensive. Over the last 10 years, with the developing interest in miniaturization in analytical chemistry with resultant solvent and sample savings, some newer miniaturization approaches to liquid extraction have been reported. These approaches have resulted in more efficient sample enrichment, faster sample preparation and lower solvent consumption. Liquid-liquid microextraction (LLME) is a single-step extraction with a very high sampleto-solvent ratio which leads to a high enrichment factor of analytes. So, conventional LLME has been proposed in several United States Environmental Protection Agency (USEPA) methods as an efficient alternative to LLE. ${ }^{8,9}$ In the past few years, a novel liquid-liquid microextraction system, termed liquid-phase microextraction (LPME) or solvent microextraction (SME), was developed. ${ }^{10,11}$ This approach is based on analyte partitioning between a drop of organic solvent (extractant phase) and the aqueous sample matrix. Different configurations of this technique have recently emerged, including static LPME, dynamic LPME, continuous-flow LPME, headspace LPME (HSLPME) and hollow fiber LPME. ${ }^{12-15}$ This strategy has attracted increasing attention in recent years because of the simple experimental setup, short analysis time and minimum use of solvent. However, several disadvantages such as microdrop instability and relative low precision are often encountered. ${ }^{16}$ Very recently, a novel microextraction technique, dispersive liquid-liquid microextraction (DLLME), based on dispersion of tiny droplets of the extraction liquid within the aqueous solution has been developed. ${ }^{17}$ It is based on a ternary component solvent system like homogeneous liquid-liquid extraction (HLLE) ${ }^{18}$ and cloud point extraction (CPE) ${ }^{19}$ The advantages of the DLLME method are rapidity, low cost and high enrichment factors. Its main drawbacks are the difficulty to automate and the necessity of using a third component (disperser solvent), which usually decreases the partition coefficient of analytes into the extractant solvent. This method has been applied for the determination of trace organic pollutants and metal ions in the environmental samples..$^{20-25}$

The analytical use of ultrasound-generated emulsions has recently found a growing interest to improve efficiency in liquid-liquid extraction since they increase the speed of the mass transfer between the two immiscible phases employed. Thus, dispersed droplets can act as efficient liquid-liquid microextractors in the continuous phase, and later they can be readily separated by centrifugation. The application of ultrasound-assisted radiation in LLE methods (USALLE) has been reported by Luque de Castro and Priego-Capote. ${ }^{26,27}$ They also successfully applied ultrasound-assisted emulsification (USAE) for the first time to determine some polar and non-polar compounds in solid plant samples. ${ }^{28}$ High extraction efficiency in a short period of time is the main advantage of USALLE. Regueiro et al. ${ }^{29}$ applied a miniaturized approach to USALLE by using a micro volume of organic phase to provide the advantage of both DLLME and USALLE. ${ }^{29}$ They have successfully applied ultrasound-assisted emulsification microextraction (USAEME) to determine some emergent contaminants and pesticides in environmental waters. Fontana et al..$^{30}$ applied this method for determination of polybrominated flame retardants in water samples. They demonstrated that USAEME is an efficient, simple, rapid and cheap extraction technique prior to $\mathrm{GC}$ analysis.

Recently, we reported a LL-DLLME method for preconcentration of silver and copper. ${ }^{31,32}$ The aim of this work is to demonstrate the use of ligandless-ultrasoundassisted emulsification microextraction (LL-USAEME) for simultaneous separation and preconcentration of trace amounts of cobalt and manganese in water samples.

\section{Experimental}

\section{Reagents}

All chemicals were analytical-reagent grade and all solutions were prepared with deionized water. The laboratory glassware (beakers and calibrated volumetric flasks) were kept overnight in a $1.4 \mathrm{~mol} \mathrm{~L}^{-1} \mathrm{HNO}_{3}$ solution. Before use, all glassware were washed with deionized water and dried. The stock standard solutions (1000.0 $\mathrm{mg} \mathrm{L}^{-1}$ ) of cobalt and manganese were obtained from Merck (Darmstadt, Germany). The working reference solutions were obtained daily by stepwise dilution from stock solution with deionized water. Buffer solutions with $\mathrm{pH}=11$ were prepared from $0.1 \mathrm{~mol} \mathrm{~L}^{-1}$ disodium hydrogen phosphate. A solution of $10 \% \mathrm{~m} / \mathrm{v} \mathrm{NaCl}$ (Merck) was prepared by dissolving of $10 \mathrm{~g}$ of $\mathrm{NaCl}$ in $100 \mathrm{~mL}$ of deionized water. The solution of alkali metal salts $(1 \% \mathrm{~m} / \mathrm{v})$ and various metal salts $(0.1 \% \mathrm{~m} / \mathrm{v})$ were used to study the interference of ions.

\section{Instrumentation}

A SensAA GBC flame atomic absorption spectrometer (Dandenong, Australia) equipped with deuterium background correction and air-acetylene burner was used for $\mathrm{Co}$ and $\mathrm{Mn}$ determinations according to instrument instruction. Cobalt and Mn hollow cathode lamps were used as radiation sources for absorbance measurements at 240.7 and $279.5 \mathrm{~nm}$, respectively. The operational parameters for each analyte were set according to the manufacturer recommendation. The acetylene gas flow rate and the 
burner height were adjusted in order to obtain the maximum absorbance signal, while aspirating the analyte solution. A Metrohm $692 \mathrm{pH}$ (Herisau, Switzerland) was used for $\mathrm{pH}$ measurements. A Centurion scientific centrifuge model 1020 D.E. (West Sussex, United Kingdom) was used to accelerate the phase separation. An ultrasonic bath with temperature control (FALC instruments S.V.1 Treviglio, Italy) model LBS2 was used to assist the emulsification process of the microextraction technique.

\section{LL-USAEME procedure}

All standard and sample solutions were prepared for analysis according to the following procedure. A volume of $8.0 \mathrm{~mL}$ of each sample was placed in a screw cap glass test tube with a conical bottom. To each test tube, $1 \mathrm{~mL}$ of $0.1 \mathrm{~mol} \mathrm{~L}^{-1}$ phosphate buffer $(\mathrm{pH} \mathrm{11)}$ and $1 \mathrm{~mL} \mathrm{NaCl}$ $10 \% \mathrm{~m} / \mathrm{v}$ were added. Further, a volume of $20.0 \mu \mathrm{L}$ of carbon tetrachloride was rapidly injected into each solution and all samples were sonicated for $15 \mathrm{~min}$ at $50{ }^{\circ} \mathrm{C}$. As a result, oil-in-water emulsions of carbon tetrachloride were formed. Emulsions were then disrupted by centrifugation at $4000 \mathrm{rpm}$ for $5 \mathrm{~min}$, which resulted in organic phase sedimentation at the bottom of the conical tube. The sedimented phase was quantitatively transferred to another test tube and $0.8 \mathrm{~mL} 0.1 \mathrm{~mol} \mathrm{~L}^{-1}$ of $\mathrm{HNO}_{3}$ in methanol was added to it. Finally, this solution was aspirated directly into the FAAS.

\section{Sample preparation}

Two certified reference materials were obtained from the National Institute for Environment Studies (NIES, Tsukuba-City, Japan) No. 3 Chlorella and NIES No. 7 Tea Leaves and were analyzed. Approximately $0.50 \mathrm{~g}$ of chlorella and $2.5 \mathrm{~g}$ of tea leaves were weighed accurately into two beakers and dissolved in concentrated nitric acid (ca. $10 \mathrm{~mL}$ ) with heating on a water bath. The solutions were cooled, diluted to $20 \mathrm{~mL}$ with de-ionized water and filtered. Then, the filtrate was made up to $50.0 \mathrm{~mL}$ with de-ionized water in a calibrated flask. An aliquot of this solution was taken individually and $\mathrm{Co}(\mathrm{II})$ and $\mathrm{Mn}$ (II) ions were determined by LL-USAEME procedure.

River and well water samples were collected in acidleached polyethylene bottles. The river water samples were collected from Rayen, Shahdad and Kohpayeh in Kerman province, Iran. The well water sample was collected from Payame Noor University, Kerman, Iran. The only pretreatment was acidification to $\mathrm{pH} 2$ with nitric acid, which was performed immediately after collection, in order to prevent adsorption of the metal ions on the flask walls. The samples were filtered before analysis through a cellulose membrane of $0.45 \mu \mathrm{m}$ pore size (Millipore, Billerica, MA, USA).

\section{Results and Discussion}

In this study combination of USAEME with FAAS was developed for determination of trace amounts of $\mathrm{Co}$ and $\mathrm{Mn}$ in water samples. Several factors that may affect the extraction process, such as type and volume of the extraction solvent, $\mathrm{pH}$, extraction time, extraction temperature, and ionic strength were optimized. The optimizations were carried out with an aqueous solution containing $4.0 \mu \mathrm{g}$ of Co and $2.4 \mu \mathrm{g}$ of $\mathrm{Mn}$.

\section{Selection of type and volume of the extraction solvent}

The type of extraction solvent is an essential consideration in USAEME for efficient extraction. It should present higher density than water, high extraction capability of the analytes and low solubility in water. Dichloromethane $\left(\mathrm{CH}_{2} \mathrm{Cl}_{2}\right)$, chloroform $\left(\mathrm{CHCl}_{3}\right)$, 1,2-dicholorobenzene (1,2-DCB) and carbon tetrachloride $\left(\mathrm{CCl}_{4}\right)$ were studied as extraction solvent. The effect of these solvents on the extraction efficiency of LL-USAEME was investigated using $30.0 \mu \mathrm{L}$ of each solvent. After the addition of $\mathrm{CHCl}_{3}$ and $\mathrm{CH}_{2} \mathrm{Cl}_{2}$ not only the cloudy state was formed but also there was no sedimented phase at the bottom of the test tube after centrifugation. This effect can be explained by the higher solubility of these solvents in water compared to the other tested solvents. Three replicate tests were performed for each of these solvents under the same conditions. The results have shown that extraction efficiency of $\mathrm{CCl}_{4}(>96 \%)$ is higher than 1, 2-DCB (92\%). Therefore, $\mathrm{CCl}_{4}$ was selected as extraction solvent for subsequent experiments.

In order to examine the effect of the extraction solvent volume, different volumes of $\mathrm{CCl}_{4}(10-60 \mu \mathrm{L})$ were used as extraction solvent to the same LL-USAEME procedure. It was observed that the highest extraction efficiency was obtained with $20.0 \mu \mathrm{L}$ of $\mathrm{CCl}_{4}$ (Figure 1). Therefore, $20.0 \mu \mathrm{L}$ of $\mathrm{CCl}_{4}$ was used for further experiments.

\section{Effect of pH on LL-USAEME}

The effect of $\mathrm{pH}$ on the LL-USAEME extraction of Co and $\mathrm{Mn}$ was studied in the $\mathrm{pH}$ range of 1-12. The $\mathrm{pH}$ of the metal sample solutions was adjusted by using $\mathrm{NaOH}$ and $\mathrm{HNO}_{3}$ solutions. As it can be seen in Figure 2, the highest extraction efficiency of both analytes were obtained at $\mathrm{pH}$ range of 10-11. Accordingly, further studies were carried out at $\mathrm{pH} 11$ by using $0.1 \mathrm{~mol} \mathrm{~L}^{-1}$ phosphate buffer solutions. 


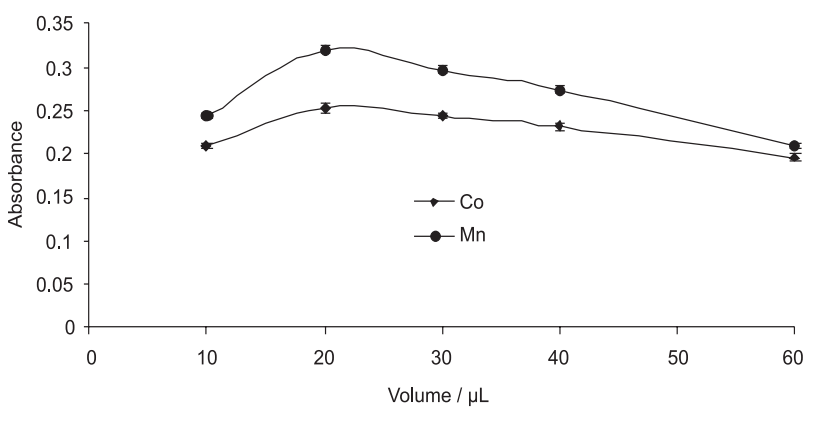

Figure 1. Effect of the extraction solvent volume $\left(\mathrm{CCl}_{4}\right)$ on the LLUSAEME of Co and Mn. Experimental conditions: $\mathrm{Co}(\mathrm{II}), 4.0 \mu \mathrm{g} ; \mathrm{Mn}(\mathrm{II})$, $2.4 \mu \mathrm{g}$; Buffer, $1 \mathrm{~mL} ; \mathrm{NaCl} 10 \% \mathrm{~m} / \mathrm{v}, 1 \mathrm{~mL}$; Extraction time, $15 \mathrm{~min}$; Extraction temperature, $50{ }^{\circ} \mathrm{C}$ and $\mathrm{CCl}_{4}, 20.0 \mu \mathrm{L}$.

Additional experiments on volume of buffer showed that 1-2 mL of buffer solution led to best results. Therefore, $1 \mathrm{~mL}$ of $0.1 \mathrm{~mol} \mathrm{~L}^{-1}$ phosphate buffer solution was used in all subsequent experiments.

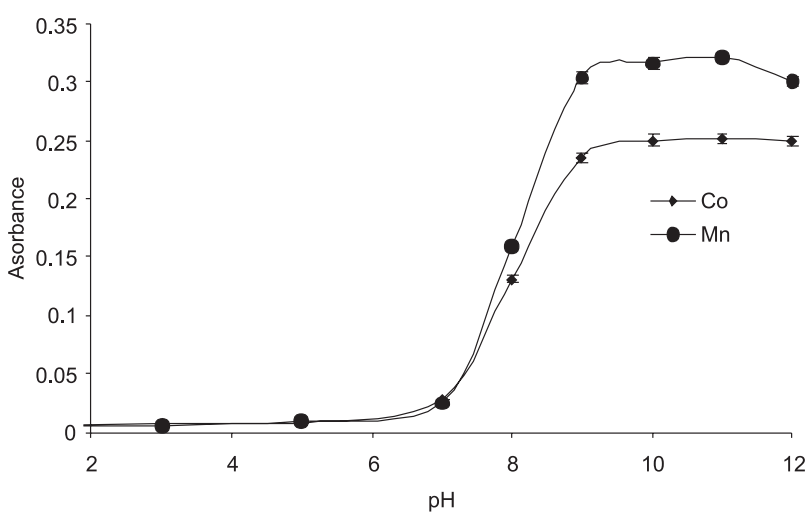

Figure 2. Effect of the $\mathrm{pH}$ of sample solution on the LL-USAEME of Co and $\mathrm{Mn}$. Experimental conditions were the same as Figure 1 except $\mathrm{pH}$.

\section{Effect of the extraction time}

In USAEME, the extraction time was defined as the interval time between the introduction of the extraction solvent $\left(\mathrm{CCl}_{4}\right)$ and the end of sonication stage. The effect of extraction time was examined in the range of 5 to $30 \mathrm{~min}$ keeping constant all other experimental conditions. The results shown that the extraction efficiency increased with increase of the extraction time to $15 \mathrm{~min}$. Reduction in the extraction efficiency was observed after $15 \mathrm{~min}$, therefore extraction time of $15 \mathrm{~min}$ was used for further experiments.

\section{Effect of extraction temperature}

Temperature could affect solubility of organic solvents in water as well as the emulsification phenomenon. Thus, temperature affected the mass-transfer process and the extraction efficiency. To determine the influence of the extraction temperature, a volume of $8.0 \mathrm{~mL}$ of an aqueous solution containing $4.0 \mu \mathrm{g}$ of Co and $2.4 \mu \mathrm{g}$ of Mn were extracted at different temperatures ranging from 30 to $60{ }^{\circ} \mathrm{C}$. The results showed that the highest extraction efficiency was obtained at $50{ }^{\circ} \mathrm{C}$. At higher temperatures, $\mathrm{CCl}_{4}$ was partially dissolved into the aqueous bulk, leading to the reduction of the extraction efficiency. Hence, $50{ }^{\circ} \mathrm{C}$ was used for further experiments.

\section{Salting out effect}

In the extraction, the solubility of many analytes in aqueous solutions decreases with increasing of ionic strength due to the salting out effect. Sodium chloride was used to investigate the influence of ionic strength on the extraction efficiency. To investigate the influence of the ionic strength on the LL-USAEME performance, several experiments were performed by adding various amounts of $\mathrm{NaCl}$ from 0.025 to $0.2 \mathrm{~g}$, while all other experimental conditions were kept constant. The resulting data showed the maximum extraction efficiency was reached in the presence of $0.1 \mathrm{~g}$ of $\mathrm{NaCl}$. Below or above this amount, a decrease on the extraction efficiency was observed. Therefore, $1 \mathrm{~mL} \mathrm{NaCl} \mathrm{10 \%} \mathrm{was} \mathrm{used} \mathrm{in} \mathrm{all} \mathrm{further}$ experiments.

\section{Effect of foreign ions}

In view of the typically high selectivity provided by FAAS, eventual interference processes may be attributed to the preconcentration step. To perform this study, various salts and metal ions were added individually to a solution containing $4.0 \mu \mathrm{g}$ of $\mathrm{Co}$ and $2.4 \mu \mathrm{g}$ of $\mathrm{Mn}$ and the developed procedure was applied. The tolerance limit was set as the concentration of the diverse ion required to cause $\pm 5 \%$ error. Table 1 shows the tolerance limits of the interference ions. The results demonstrate that the presence of large amounts of species commonly present in water samples had no significant effect on the LL-USAEAE of both analytes.

\section{Calibration, precision and detection limit}

Under the optimized conditions, calibration curves were constructed for the determination of $\mathrm{Co}$ and $\mathrm{Mn}$ according to the LL-USAEME procedure. The calibration graphs were linear in the range of 3.0 to $2000.0 \mathrm{ng} \mathrm{mL}^{-1}$ and 2.0 to $850.0 \mathrm{ng} \mathrm{mL}^{-1}$ for $\mathrm{Co}(\mathrm{II})$ and $\mathrm{Mn}$ (II), respectively. The equations for the lines were $A=0.4998 \times 10^{-3} C+0.0040$ $(R=0.9998)$ and $A=1.0701 \times 10^{-3} C+0.0031(R=0.9998)$, respectively. In these equations, $A$ is the absorbance value, $C$ is the concentration of $\mathrm{Co}$ and $\mathrm{Mn}\left(\mathrm{ng} \mathrm{mL} \mathrm{m}^{-1}\right)$ and $\mathrm{R}$ is the correlation coefficient. The limits of detection of 
Table 1. Tolerance limit of foreign ions

\begin{tabular}{lcc}
\hline Foreign ions & \multicolumn{2}{c}{ Interference/analyte ion ratio } \\
& $\mathrm{Co}(\mathrm{II})$ & $\mathrm{Mn}(\mathrm{II})$ \\
\hline $\mathrm{H}_{2} \mathrm{PO}_{4}^{--}$ & 5000 & 5000 \\
$\mathrm{HPO}_{4}^{2-}$ & 5000 & 5000 \\
$\mathrm{Ca}^{2+}, \mathrm{Mg}^{2+}$ & 1300 & 1200 \\
$\mathrm{Zn}^{2+}$ & 1200 & 1200 \\
$\mathrm{Ni}^{2+}$ & 1000 & 1200 \\
$\mathrm{~Pb}^{2+}$ & 200 & 400 \\
$\mathrm{Al}^{3+}$ & 50 & 100 \\
$\mathrm{As}^{3+}$ & 1200 & 1500 \\
$\mathrm{Cd}^{2+}$ & 300 & 200 \\
$\mathrm{Fe}^{3+}$ & 500 & 350 \\
$\mathrm{Pd}^{2+}$ & 500 & 500 \\
$\mathrm{Hg}^{2+}$ & 250 & 300 \\
$\mathrm{Sb}^{3+}$ & 400 & 400 \\
$\mathrm{Cr}^{3+}$ & 200 & 300 \\
$\mathrm{Cu}^{2+}$ & 1300 & 1500 \\
\hline $\mathrm{Exp}^{2+}$ & &
\end{tabular}

Experimental conditions were the same as Figure 1.

this procedure for $\mathrm{Co}(\mathrm{II})$ and $\mathrm{Mn}(\mathrm{II})$ ions were 0.8 and $0.5 \mathrm{ng} \mathrm{mL}^{-1}$, respectively $\left(3 \mathrm{~S}_{\mathrm{b}} / \mathrm{m}\right)$. Eight replicates of a mixture of $100.0 \mathrm{ng} \mathrm{mL}^{-1} \mathrm{Co}$ and $50.0 \mathrm{ng} \mathrm{mL}^{-1} \mathrm{Mn}$ gave a mean absorbance of 0.055 and 0.061 with relative standard deviations of 3.2 and $2.9 \%$, respectively.

The preconcentration factor is defined as the ratio of the concentration in the organic drop to the concentration in the initial bulk phase. ${ }^{15}$ The preconcentration factors obtained were 12.5 for both analytes. The enhancement factor was defined as the ratio of the slope of the calibration curve for the LL-USAEME procedure to that obtained without preconcentration. ${ }^{15}$ In the proposed procedure, enhancement factors were 6.25 and 9.51 for Co and $\mathrm{Mn}$, respectively.

\section{Analysis of certified reference materials and synthetic samples}

The accuracy and applicability of the proposed method was studied for the determination of $\mathrm{Co}(\mathrm{II})$ and $\mathrm{Mn}$ (II) ions in chlorella and tea leaves CRMs. The results are shown in Table 2. It was found that there is no significant difference between results obtained by the proposed procedure and the certified values. These results indicate the applicability of the developed procedure for simultaneous preconcentration of $\mathrm{Co}$ and $\mathrm{Mn}$. Also, since no water standard samples were available for testing the validity of the proposed method for analysis of water samples in our laboratory, the method was applied to synthetic samples. Accordingly, various synthetic mixtures simulating different cations were prepared. Aliquots of the synthetic mixture were taken, $\mathrm{pH}$ was adjusted to 11 with buffer and then the LL-USAEME procedure applied. The results are given in Table 3 .

Table 2. Determination of $\mathrm{Co}(\mathrm{II})$ and $\mathrm{Mn}$ (II) in certified reference materials

\begin{tabular}{lcc}
\hline Sample & Certified value $/ \mu \mathrm{g}$ & Found $\mathrm{a} / \mu \mathrm{g}$ \\
\hline NIES, No. 3 & Co $0.87 \pm 0.05$ & Co $0.90 \pm 0.04$ \\
Chlorella & Mn $69 \pm 5$ & Mn $70.2 \pm 2.5$ \\
NIES, No. 7 & Co 0.12 & Co $0.12 \pm 0.01$ \\
Tea Leaves & Mn 7.00 & Mn $6.9 \pm 0.3$
\end{tabular}

${ }^{\mathrm{a}}$ Average of four determinations \pm standard deviation.

Applicability of the proposed procedure for determination of Co and Mn in water

The proposed procedure was applied for the determination of $\mathrm{Co}$ and $\mathrm{Mn}$ in water samples. The results are shown in Table 4.

Recoveries of $\mathrm{Co}$ and $\mathrm{Mn}$ from water samples spiked with $\mathrm{Co}(\mathrm{II})$ and $\mathrm{Mn}$ (II) were also studied (Table 4). According to these results, the added $\mathrm{Co}$ (II) and $\mathrm{Mn}$ (II) ions can be quantitatively recovered from the water samples by the proposed procedure. These results demonstrate the applicability of the procedure for $\mathrm{Co}$ and Mn determination in water samples.

\section{Comparison}

A comparison of the LL-USAEME procedure with other reported extraction methods ${ }^{33-38}$ for Co and $\mathrm{Mn}$ extraction from water samples is prresented in Table 5. The

Table 3. Determination of Co(II) and Mn(II) in synthetic samples

\begin{tabular}{|c|c|c|}
\hline Sample & Composition/ $\mu \mathrm{g}$ & Found $^{a} / \mu \mathrm{g}$ \\
\hline Synthetic samples, No. 1 & $\begin{array}{c}\mathrm{Ca}, 150 ; \mathrm{Mg}, 40 ; \mathrm{Cd}, 20 ; \mathrm{Ni}, 30 ; \mathrm{Cu}, 40 ; \mathrm{Fe}, 100 ; \mathrm{Pb}, 60 ; \mathrm{Zn}, 50 ; \mathrm{As}, 30 ; \mathrm{Hg}, \\
20 ; \mathrm{Co}, 10.0 ; \mathrm{Mn}, 10.0\end{array}$ & $\begin{array}{l}\text { Co } 10.1 \pm 0.5 \\
\text { Mn } 9.8 \pm 0.4\end{array}$ \\
\hline Synthetic samples, No. 2 & $\begin{array}{c}\mathrm{Pb}, 100 ; \mathrm{Cd}, 60 ; \mathrm{Sb}, 50 ; \mathrm{Zn}, 40 ; \mathrm{Cr}, 80 ; \mathrm{Al}, 40 ; \mathrm{Mg}, 100 ; \mathrm{Ca}, 500 ; \mathrm{Ni}, 50 ; \mathrm{Cu} \\
40 ; \mathrm{Sb}, 60, \mathrm{Pd}, 60 ; \mathrm{Co}, 15.0 ; \mathrm{Mn}, 15.0\end{array}$ & $\begin{array}{l}\text { Co } 14.8 \pm 0.6 \\
\text { Mn } 14.7 \pm 0.7\end{array}$ \\
\hline
\end{tabular}

${ }^{\mathrm{a} A v e r a g e ~ o f ~ f o u r ~ d e t e r m i n a t i o n s ~} \pm$ standard deviation. 
Table 4. Determination of $\mathrm{Co}(\mathrm{II})$ and $\mathrm{Mn}(\mathrm{II})$ in water samples

\begin{tabular}{|c|c|c|c|c|}
\hline Sample & Found $^{\mathrm{a}} /\left(\mathrm{ng} \mathrm{mL}^{-1}\right)$ & Added/(ng mL-1) & Found/(ng mL $\left.L^{-1}\right)$ & Recovery/\% \\
\hline River Water (Rayen, Kerman) & $\begin{array}{c}\text { Co } 4.90 \pm 0.18 \\
M n: 5.94 \pm 0.25\end{array}$ & $\begin{array}{l}\text { Co } 5.0 \\
\text { Mn } 5.0\end{array}$ & $\begin{array}{l}\text { Co } 10.02 \pm 0.39 \\
\text { Mn } 11.09 \pm 0.42\end{array}$ & $\begin{array}{l}102.4 \\
103.0\end{array}$ \\
\hline River Water (Shahdad, Kerman) & $\begin{array}{l}\text { Co } 5.42 \pm 0.21 \\
\operatorname{Mn} 6.38 \pm 0.23\end{array}$ & $\begin{array}{l}\text { Co } 5.0 \\
\operatorname{Mn} 5.0\end{array}$ & $\begin{array}{c}\text { Co } 10.37 \pm 0.41 \\
\text { Mn } 11.41 \pm 0.43\end{array}$ & $\begin{array}{c}99.0 \\
100.6\end{array}$ \\
\hline River Water (Kohpayeh, Kerman) & $\begin{array}{c}\text { Co } 6.18 \pm 0.23 \\
\text { Mn } 5.23 \pm 0.18\end{array}$ & $\begin{array}{l}\text { Co } 5.0 \\
\operatorname{Mn} 5.0\end{array}$ & $\begin{array}{c}\text { Co } 11.26 \pm 0.41 \\
\text { Mn } 10.36 \pm 0.40\end{array}$ & $\begin{array}{l}101.6 \\
102.6\end{array}$ \\
\hline Well Water (Payame Noor University of Kerman) & $\begin{array}{l}\operatorname{Co} 4.61 \pm 0.16 \\
\operatorname{Mn} 9.73 \pm 0.41\end{array}$ & $\begin{array}{l}\text { Co } 5.0 \\
\operatorname{Mn} 5.0\end{array}$ & $\begin{array}{c}\text { Co } 9.68 \pm 0.38 \\
\operatorname{Mn} 14.65 \pm 0.58\end{array}$ & $\begin{array}{c}101.4 \\
98.4\end{array}$ \\
\hline
\end{tabular}

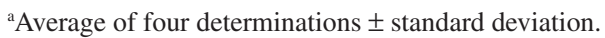

Table 5. Comparison of the LL-USAEME proposed procedure with other reported procedures for preconcentration of Co and Mn

\begin{tabular}{|c|c|c|c|c|c|c|}
\hline Procedure & Analyte & Instrumental method & Linear range $\left(\mathrm{ng} \mathrm{mL}^{-1}\right)$ & RSD \% & LOD $\left(\mathrm{ng} \mathrm{mL}^{-1}\right)$ & Ref. \\
\hline$\overline{\mathrm{CPE}}$ & Co & FAAS & $0.01-0.2$ & 1.5 & 2.1 & 33 \\
\hline DLLME & Co & FAAS & $3-100$ & 2.3 & 0.9 & 34 \\
\hline DLLME & Co & $\begin{array}{c}\text { Fiber optic-linear array } \\
\text { spectrophotometry }\end{array}$ & $1-70$ & $<4$ & 0.2 & 35 \\
\hline $\mathrm{CPE}$ & $\mathrm{Mn}$ & FAAS & --- & --- & 5 & 36 \\
\hline $\mathrm{CPE}$ & $\mathrm{Mn}$ & FAAS & $1.7-150$ & 5.4 & 0.5 & 37 \\
\hline $\mathrm{CPE}$ & $\mathrm{Mn}$ & FAAS & $2.2-150$ & --- & 0.7 & 38 \\
\hline LL-USAEME & $\begin{array}{l}\mathrm{Co} \\
\mathrm{Mn}\end{array}$ & FAAS & $\begin{array}{l}3-2000 \\
2-850\end{array}$ & $\begin{array}{l}3.2 \\
2.9\end{array}$ & $\begin{array}{l}0.8 \\
0.5\end{array}$ & Present work \\
\hline
\end{tabular}

obtained detection limits by the LL-USAEME procedure are comparable to most of those reported in the literature.

\section{Conclusions}

The present paper reported combination of LL-USAEME with FAAS for preconcentration and determination of trace amounts of Co and $\mathrm{Mn}$ (at ng mL $\mathrm{mL}^{-1}$ level) in water samples. LL-USAEME was a sensitive, efficient, inexpensive and simple method for preconcentration and separation of trace amounts of Co and $\mathrm{Mn}$ using low sample volumes. In addition, it is important to point out that LL-USAEME is a low organic solvent consuming extraction technique, which turns it into a low cost technique. In the developed procedure, the consumption of the toxic organic solvent (at $\mu \mathrm{L}$ level) was minimized without negatively affecting the sensitivity.

\section{References}

1. Yang, M.; Li, J. X.; Wang, J. H.; Talanta 2007, 72, 1710.

2. Yu, Y. L.; Du, Z.; Wang, J. H.; J. Anal. At. Spectrom. 2007, 22, 650.

3. Venkatesh, G.; Singh, A. K.; Talanta 2007, 71, 282.

4. Looser, P.W.; Berg, M.; Fent, K.; Muhlemann, J.; Schwarzenbach, R. P.; Anal. Chem. 2000, 72, 5136.

5. Rial Otero, R.; Cancho Grande, B.; Simal Gandara, J.; J. Chromatogr., A 2003, 992, 121.
6. Westbom, R.; Thorneby, L.; Zorita, S.; Mathiasson, L.; Bjorklund, E.; J. Chromatogr., A 2004, 1033, 1.

7. Conka, K.; Drobna, B.; Kocan, A.; Petrik, J.; J. Chromatogr., A 2005, 1084, 33.

8. US EPA Method 8011, American Society for Testing and Materials, Philadelphia: PA, 1992, http://www.accustandard.com/asi/pdfs/ epa_methods/8011.pdf, accessed in December, 2009.

9. US EPA Method 552.3, American Society for Testing and Materials, Philadelphia: PA, 2003, http://www.caslab.com/ EPA-Methods/PDF/EPA-Method-5523rev10.pdf, accessed in December, 2009.

10. Jeannot, M. A.; Cantwell, F. F.; Anal. Chem. 1996, 68, 2236.

11. He, Y.; Lee, H. K.; Anal. Chem. 1997, 69, 4634.

12. Psillakis, E.; Kalogerakis, N.; J. Chromatogr., A 2003, 999, 145.

13. Rasmussen, K. E.; Pedersen-Bjergaard, S.; TrAC, Trends Anal. Chem. 2004, 23, 1.

14. Jiang, X.; Basheer, C.; Zhang, J.; Lee, H. K.; J. Chromatogr., A 2005, 1087, 289.

15. J. Ma, J.; Zhang, J.; Du, X.; Lei, X.; Li, J.; Microchim. Acta 2010, 168, 153.

16. Xu, H.; Liao, Y.; Yao, J.; J. Chromatogr., A 2007, 1167, 1.

17. Rezaee, M.; Assadi, Y.; Milani Hosseini, M. R.; Aghaee, E.; Ahmadi, F.; Berijani, S.; J. Chromatogr., A 2006, 1116, 1.

18. Takagai, Y.; Akiyama, R.; Igarashi, S.; Anal. Bioanal. Chem. 2006, $385,888$.

19. Carabias-Martinez, R.; Rodriguez-Gonzalo, E.; DominguezAlvarez, J.; Hernandez-Mendez, J.; Anal. Chem. 1999, 71, 2468. 
20. Fatahi, N.; Samadi, S.; Assadi, Y.; Milani Hosseini, M. R.; J. Chromatogr., A. 2007, 1169, 63.

21. Li, S.; Cai, S.; Hu, W.; Chen, H.; Liu, H.; Spectrochim. Acta, Part B 2009, 64, 666.

22. Dadfarnia, S.; Salmanzadeh, A. M.; Haji Shabani, A. M.; Anal. Chim. Acta 2008, 623, 163.

23. Ma, J. J.; Du, X.; Zhang, J. W.; Li, J. C.; Wang, L. Z.; Talanta 2009, 80, 980.

24. Liang, P.; Sang, H.; Anal. Biochem. 2008, 380, 21.

25. Rivas, R. E.; Garcia, I. L.; Cordoba, M. H.; Spectrochim. Acta, Part B 2009, 64, 329.

26. Luque de Castro, M. D.; Priego-Capote, F.; Analytical Applications of Ultrasound in Techniques and Instrumentations in Analytical Chemistry, vol. 26, Elsevier: Amsterdam, 2007.

27. Luque de Castro, M. D.; Priego-Capote, F.; Talanta 2007, 72, 321.

28. Perez-Serradilla, J. A.; Priego-Capote, F.; Luque de Castro, M. D.; Anal. Chem. 2007, 79, 6767.

29. Regueiro, J.; Llompart, M.; Garcia-Jares, C.; GarciaMonteagudo, J. C.; Cela, R.; J. Chromatogr., A 2008, 1190, 27.
30. Fontana, A. R.; Wuilloud, R. G.; Martinez, L. D.; Altamirano, J. C.; J. Chromatogr., A 2009, 1216, 147.

31. Mohammadi, S. Z.; Afzali, D.; Taher, M. A.; Baghelani, Y. M.; Talanta 2009, 80, 875.

32. Mohammadi, S. Z.; Afzali, D.; Baghelani, Y. M.; Anal. Chim. Acta 2009, 653, 173.

33. Ghaedi, M.; Shokrollahi, A.; Ahmadi, F.; Rajabi, H. R.; Soylak, M.; J. Hazard. Mater. 2008, 150, 533.

34. Baliza, P. X.; Teixeira, L. S. G.; Lemos, V. A.; Microchem. J. 2009, 93, 220.

35. Shokoufi, N.; Shemirani, F.; Assadi, Y.; Anal. Chim. Acta 2007, $597,349$.

36. Doroschuk, V. O.; Lelyushok, S. O.; Ishchenko, V. B.; Kulichenko, S. A.; Talanta 2004, 64, 853.

37. Lemos, V. A.; Baliza, P. X.; De Carvalho, A. L.; Oliveira, R. V.; Teixeira, L. S. G.; Bezerra, M. A.; Talanta 2008, 77, 388.

38. Lemos, V. A.; David, G. T.; Microchem. J. 2010, 94, 42.

Submitted: February 24, 2010

Published online: August 24, 2010 